\title{
Enzymatic Activity in Essential Oil-Treated and Pathogen-Inoculated Corn Plants
}

\author{
Ronice Alves Veloso ${ }^{1}$, Talita Pereira de Souza Ferreira ${ }^{1}$, Daniel Debona ${ }^{2}$, Raimundo Wagner de Souza Aguiar ${ }^{1}$, \\ Alex Sander Rodrigues Cangussu ${ }^{1}$, Aloísio Freitas Chagas Júnior ${ }^{1} \&$ Gil Rodrigues dos Santos ${ }^{1}$ \\ ${ }^{1}$ Universidade Federal do Tocantins, Campus Gurupi, TO, Brazil \\ ${ }^{2}$ Universidade Federal de Lavras, Lavras, MG, Brazil \\ Correspondence: Gil Rodrigues dos Santos, Universidade Federal do Tocantins, Campus Gurupi, Rua Badejós, \\ Lote 7, Chácaras 69/72, Zona Rural, 77402-970, TO, Brazil. Tel: 55-63-9951-8812. E-mail: gilrsan@uft.edu.br
}

Received: May 2, $2018 \quad$ Accepted: July 17, $2018 \quad$ Online Published: September 15, 2018

doi:10.5539/jas.v10n10p171 URL: https://doi.org/10.5539/jas.v10n10p171

\begin{abstract}
Bipolaris maydis and Exserohilum turcicum are important fungal pathogens that cause leaf blight in corn whose control have been difficult. Essential oils are a promising and environmentally friendly alternative for disease management, but the mechanisms of action remain poorly studied. Here, we aimed to assess the effect of $B$. maydis and E. turcicum as well as the essential oil of Morinda citrifolia in the activity of plant defense enzymes in corn plants. Experiments were carried out in a completely randomized design with three replications and six treatments as they follow: (T1): corn plants inoculated with B. maydis; (T2): corn plants inoculated with $E$. turcicum; (T3): corn plants treated with essential oil of M. citrifolia $(0.25 \%)$ and inoculated with B. maydis; (T4): corn plants treated with essential oil of $M$. citrifolia $(0.25 \%)$ and inoculated with E. turcicum; (T5): corn plants treated with essential oil of M. citrifolia $(0.25 \%)$; and (T6): corn plants non-inoculated and treated with distilled water. Protein content (PC) and activities of the enzymes ascorbate peroxidase, catalase, chitinase (CHI), peroxidase (POX) and superoxide dismutase (SOD) were assessed. PC was significantly decreased, whereas CHI and SOD activity was higher in T1-T5 compared to T6. T4 and T5 significantly increased POX activity relative to T6. Therefore, our findings suggest that the essential oil of $M$. citrifolia may play an active role in disease control by activating defense enzymes in corn plants.
\end{abstract}

Keywords: Bipolaris maydis, Exserohilum turcicum, Morinda citrifolia, resistance induction

\section{Introduction}

Corn (Zea mays L.) is one of the most important cereals for human and animal consumption and it is grown for grain and forage. Moreover, its demand for both food and biofuel is increasing. Corn ranks first in production, accounting for 1,052 million metric tons in the world. Brazil is the third largest producer with $9 \%$ of the world production, after USA (34\%) and China (21\%) (USDA, 2018).

Several fungal diseases, notably southern leaf blight (SLB) and northern leaf blight (NLB), caused by Bipolaris maydis (teleomorph: Cochliobolus heterostrophus) and Exserohilum turcicum (teleomorph: Setosphaeria turcica), respectively, are known to affect corn production worldwide. SLB caused one of the most devastating epidemics in Plant Pathology's history; in 1970, due to the use of cytoplasmic male sterile corn (cms-T), that is highly susceptible to the pathogen's race T, the average loss in yield in the U.S. Corn Belt was $20-30 \%$ resulting in a monetary loss of 1 billion dollars (Ullstrup, 1972). Nowadays, SLB is considered to be the most important and wide spread corn leaf disease around the world and it is prevalent in warm humid temperate to tropical regions, where temperatures ranges from $20-30{ }^{\circ} \mathrm{C}$ during cropping period (Singh \& Srivastava, 2012). NLB is reported to be severe under moderate $\left(15-25^{\circ} \mathrm{C}\right)$ and dew heavy (Levy \& Cohen, 1983), with crop losses exceeding $50 \%$ if NLB becomes severe prior to flowering (Raymundo \& Hooker, 1981; Tefferi et al., 1996). Different strategies, including cultural practices, genetic resistance and fungicide application can be employed in SLB and NLB management. Crop rotation is an important alternative to reduce initial inoculum; however, sometimes it is difficult to find a profitable crop to replace corn. Some resistance genes have been identified and incorporated in commercial hybrids, but genetic variation in pathogen population may become it ineffective (Belcher et al., 2012). Broad-spectrum fungicides, including propiconazole, fluazinam, benzovindiflupyr, chlorotalonil and mancozebe were demonstrated to be effective, but pathogen sensitivity to some of them has been shown to 
decrease due to long-term large-scale use of a single fungicide (Chen et al., 2018; Hou et al., 2018). Therefore, it becomes necessary to find novel alternatives for SLB and NLB control in order to decrease the risk of pathogens overcoming resistance genes and fungicide resistance development.

Plant essential oils have shown great potential in disease control. In vitro, essential oil of Callistemon citrinus and Cymbopogon citratus were demonstrated to completely inhibit the mycelial growth of Alternaria padwickii and Bipolaris oryzae and experiments in the field showed that brown spot severity was reduced by $20-80 \%$ in rice (Nguefack et al., 2013). Essential oils of cinnamon, citronella, lemongrass, clove, tea tree, thyme, neem and eucalyptus were promising for the control of coffee rust since they inhibited germination of urediniospores of Hemileia vastatrix; transmission electron microscopy analysis showed that urediniospores exposed to oils of clove, citronella and thyme promoted cellular disorganization and cytoplasmic vacuolization (Pereira et al., 2012). Total inhibition of urediniospore germination of Phakopsora pachyrhizi was also found after treatment with essential oils of Hyptis marrubioides, Aloysia gratissima and Cordia verbenacea and their curative application reduced area under the Asian rust curves by 33-41\% (Silva et al., 2014). In maize, essential oil of Cymbopogon citratus reduced the progress of the Curvularia leaf spot when applied preventively and it was also showed to inhibit $100 \%$ of conidia germination, but not mycelial growth of Curvularia lunata (Mourão et al., 2017). In addition, we have demonstrated that essential oil of Morinda citrifolia inhibited conidia germination of E. turcicum and reduced area under the disease progress curve in preventive applications in corn (Silva et al., 2017).

Despite the reports of their effectiveness against several diseases, mechanisms of the action of essential oils remain elusive. Although a direct effect in pathogen is well documented (Pereira et al., 2012; Nguefack et al., 2013; Silva et al., 2014, 2017; Mourão et al., 2017), an indirect effect, by inducing plant defenses, cannot be ruled out. Therefore, this work aimed to assess the effect of B. maydis and E. turcicum as well as the essential oil of $M$. citrifolia in the activity of defense enzymes in corn plants.

\section{Material and Methods}

Experiments were carried out in a completely randomized design with three replicates and six treatments as they follow: (T1): corn plants inoculated with Bipolaris maydis; (T2): corn plants inoculated with Exserohilum turcicum; (T3): corn plants sprayed with essential oil of M. citrifolia $(0.25 \%)$ and inoculated with $B$. maydis; (T4): corn plants sprayed with essential oil of M. citrifolia $(0.25 \%)$ and inoculated with E. turcicum; (T5): corn plants sprayed with essential oil of M. citrifolia $(0.25 \%)$; (T6): corn plants sprayed with distilled water (control). One pot with three plants was considered as experimental unit. B. maydis and E. turcicum were chosen because their importance in limiting corn yield in the region of Gurupi (TO, Brazil). M. citrifolia was selected because we demonstrated previously its potential to control E. turcicum (Silva et al., 2017).

Five corn seeds (hybrid 30F53YH) were sown in 2 L pots, filled with Red-Yellow Latosol (Oxisol) and cattle manure (2:1) as substrate. After emergence, each pot was thinned to three seedlings and watered daily with the aid of a watering can.

Essential oil of M. citrifolia was obtained from ripe fruits collected in the region of Gurupi as described elsewhere (Silva et al., 2017). Fruits were washed in running water, cut in small cubes and submitted to the extraction of essential oil by the hydrodistillation method. In a round-bottom flask $200 \mathrm{~g}$ of noni ripe fruits were added. Following this, the flask was attached to Clevenger distiller for a two-hour period. After the extraction, the essential oil was collected in the supernatant form, placed in amber bottle, identified, and stored at $4{ }^{\circ} \mathrm{C}$. A stock solution of essential oil at $1 \%$ was prepared using a $1 \%$ Tween 80 solution as a dispersing agent. From the stock solution, a dilution was performed in order to obtain a concentration of $0.25 \%$ of essential oil of $M$. citrifolia.

Plants from the treatments $\mathrm{T} 1$ and $\mathrm{T} 2$ were inoculated with a spore suspension of $10^{4}$ conidia $\mathrm{mL}^{-1}$ of $B$. maydis and E. turcicum, respectively. Conidia were obtained from corn leaves (hybrid 30F53YH) collected in a commercial field in Gurupi and were incubated in a moisture chamber until fungal sporulation. Then, conidia were transferred to the PDA medium in Petri dishes $(90 \mathrm{~mm})$ and incubated at $25^{\circ} \mathrm{C}$ and photoperiod of $12 \mathrm{~h}$ of light until the mycelial growth reached the borders of the plates. Subsequently, the conidia were water-removed with the aid of a soft bristle brush and quantified in a Neubauer chamber and calibrated to the concentration described above. Conidia suspension was applied as a fine mist to the adaxial leaf blades of each plant until runoff using a VL Airbrush atomizer (Paasche Airbrush Co., Chicago). Plants were kept in a moisture chamber in the darkness for $24 \mathrm{~h}$ at $25 \pm 2{ }^{\circ} \mathrm{C}$. Then, plants were brought to the environment condition $\left(30 \pm 2{ }^{\circ} \mathrm{C}\right)$ for further $24 \mathrm{~h}$. 
The treatments T3, T4 and T5 were sprayed with $20 \mathrm{~mL}$ of $0.25 \%$ essential oil solution, whereas the treatment T6 was sprayed just with distilled water and plants were kept at $25 \pm 2{ }^{\circ} \mathrm{C}$. Two hours later, the treatments $\mathrm{T} 3$ and T4 were inoculated with B. maydis and E. turcicum, respectively. Thus, plants were kept in a moisture chamber in the darkness for $24 \mathrm{~h}$ at $25 \pm 2{ }^{\circ} \mathrm{C}$. Subsequently, plants were kept under environmental conditions $\left(30 \pm 2{ }^{\circ} \mathrm{C}\right)$.

Twenty-four hours after keeping plants under environmental conditions, corn leaves of the three plants of each replication were collected in order to obtain the crude extract, that was used in the determination of enzymatic activity post-inoculation of the respective treatments.

To obtain the crude extracts, $200 \mathrm{mg}$ of leaf tissue sampled in each treatment were weighed and ground in liquid nitrogen with $50 \%$ polyvinylpolypyrrolidone (PVPP). Then, $375 \mu \mathrm{L}$ of $400 \mathrm{mM}$ potassium phosphate buffer ( $\mathrm{pH}$ 7.8), $15 \mu \mathrm{L}$ of $10 \mathrm{mM}$ ethylenediaminetetraacetic acid (EDTA), $75 \mu \mathrm{L}$ of $200 \mathrm{mM}$ ascorbic acid and $1.035 \mathrm{~mL}$ of distilled sterilized water were added. Crude leaf extracts were centrifuged at $13,000 \times \mathrm{g}$ for $10 \mathrm{~min}$ at $4{ }^{\circ} \mathrm{C}$ and supernatants were recovered and stored in freezer at $-20^{\circ} \mathrm{C}$ for further enzymatic activity determination.

Protein was quantified according to Bradford (1976). In test tubes, $50 \mu \mathrm{L}$ of corn leaf extract and $1.5 \mathrm{~mL}$ of Bradford dye (Quick StartTM Bradford 1x) were shaken on a tube shaker and incubated in the darkness for 5 $\min$. Then, absorbance was read in a spectrophotometer at $595 \mathrm{~nm}$. Protein concentration was determined using a standard curve, prepared with bovine serum albumin (BSA), ranging from 0 to $100 \mu \mathrm{g} \mathrm{mL}^{-1}$. Results were expressed as $\mu \mathrm{g} \cdot \mathrm{mL}^{-1}$ for total protein and as $\mu \mathrm{mol}$ protein $\cdot \mathrm{min}^{-1}$ for APX, CAT, CHI, POX and SOD.

Activity of ascorbate peroxidase (APX) was determined at $290 \mathrm{~nm}$ and $25{ }^{\circ} \mathrm{C}$ by hydrogen peroxide $\left(\mathrm{H}_{2} \mathrm{O}_{2}\right)$ degradation (Nakano \& Asada, 1981). The reaction mixture consisted in $100 \mu \mathrm{L}$ of the crude extract, $2.7 \mathrm{~mL}$ of $0.5 \mathrm{mM}$ ascorbate buffer and $200 \mu \mathrm{L}$ of $30 \mathrm{mM} \mathrm{H}_{2} \mathrm{O}_{2}$.

Activity of peroxidase (POX) was determined at $25{ }^{\circ} \mathrm{C}$ through direct spectrophotometric method by the measurement of the conversion of guaiacol into tetraguaiacol at $470 \mathrm{~nm}$ (Kar \& Mishra, 1976). The reaction mixture had $0.05 \mathrm{~mL}$ of the crude extract and $2.55 \mathrm{~mL}$ of a solution containing $0.05 \mathrm{~mL}$ of $0.2 \mathrm{M}$ guaiacol and $0.5 \mathrm{~mL}$ of $0.38 \mathrm{M} \mathrm{H}_{2} \mathrm{O}_{2}$ and $2.0 \mathrm{~mL}$ of $0.02 \mathrm{M}$ sodium acetate buffer ( $\mathrm{pH} 5.0$ ).

Activity of superoxide dismutase (SOD) was determined at $560 \mathrm{~nm}$ (Giannopolitis \& Ries, 1977; Del Longo et al., 1993). In test tubes, $0.1 \mathrm{~mL}$ of the crude extract was combined with $1.0 \mathrm{~mL}$ of $50 \mathrm{mM}$ potassium phosphate buffer (pH 7.8), $0.02 \mathrm{~mL}$ of $0.1 \mathrm{mM}$ EDTA, $0.4 \mathrm{~mL}$ of $14 \mathrm{mM} \mathrm{L}$-methionine and $0.2 \mathrm{~mL}$ of $0.1 \mu \mathrm{M}$ nitro-blue tetrazolium (NBT). The reaction was started by adding $0.02 \mathrm{~mL}$ of $2 \mu \mathrm{M}$ riboflavin. The test tubes were illuminated for five minutes. Two blanks were prepared with the incubation without the crude extract: one was not illuminated and used to zero the spectrophotometer and the other was illuminated together with the samples to determine NBT photoreduction.

For catalase (CAT) determination, reaction mixture comprised $0.05 \mathrm{~mL}$ of the crude extract and $2.95 \mathrm{~mL}$ of 50 $\mathrm{mM}$ potassium phosphate buffer ( $\mathrm{pH}$ 7.8) and $20 \mathrm{mM} \mathrm{H}_{2} \mathrm{O}_{2}$ (Cakmak \& Marschner, 1992). The decrease in absorbance was recorded at $240 \mathrm{~nm}$ for five minutes, with readings every $30 \mathrm{~s}$.

Activity of chitinase (CHI) was assessed based on the release of soluble "CM-chitin-RBV" fragments, from remazol-bright-violet-labeled carboxymethylated chitin (CM-chitin-RBV) determined at $550 \mathrm{~nm}$ (Wirth \& Wolf, 1990). The reaction mixture consisted in $0.2 \mathrm{~mL}$ of the crude extract, $0.6 \mathrm{~mL}$ of $0.1 \mathrm{M}$ sodium acetate buffer $(\mathrm{pH}$ $5.0)$ and $0.2 \mathrm{~mL}$ of "CM-chitin-RBV" $\left(2.0 \mathrm{mg} \mathrm{mL}^{-1}\right)$. Then, samples were incubated at $40{ }^{\circ} \mathrm{C}$ for 20 minutes and reaction was stopped by adding $0.2 \mathrm{~mL}$ of $1 \mathrm{M} \mathrm{HCl}$, cooled in an ice bath and centrifuged at $10,000 \mathrm{~g}$ for five minutes.

Data were submitted to the analysis of variance and means were compared based on Tukeys test $(\mathrm{P} \leq 0.05)$, using the software Minitab (version 18; Minitab Corporation).

\section{Results}

Figure 1 shows protein content and activities of the enzymes CHI, CAT, SOD, APX and POX in corn plants that were inoculated with B. maydis or E. turcicum and sprayed with the essential oil of $M$. citrifolia or distilled water as well as combinations of essential oil of M. citrifolia spraying + B. maydis or E. turcicum inoculation. 

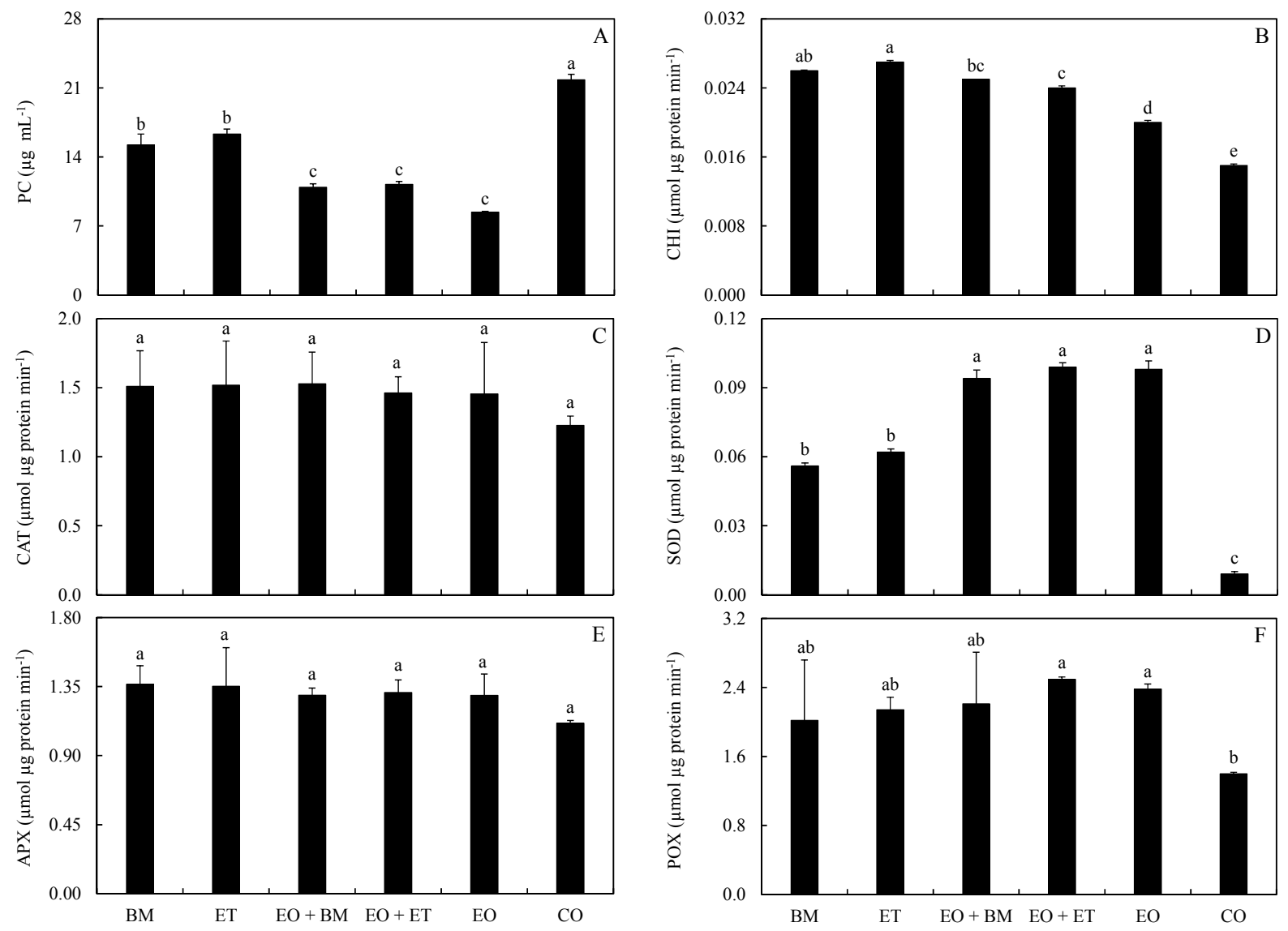

Figure 1. Protein content (PC) (A) and activities of chitinase (CHI) (B), catalase (CAT) (C), superoxide dismutase (SOD) (D), ascorbate peroxidase (APX) (E) and peroxidase (POX) (F), determined in leaves of corn plants that were inoculated with Bipolaris maydis (BM), Exserohilum turcicum (ET), sprayed with essential oil of Morinda citrifolia $(0.25 \%)+$ inoculated with B. maydis $(\mathrm{EO}+\mathrm{BM})$, sprayed with essential oil of $M$. citrifolia $(0.25 \%)+$ inoculated with E. turcicum $(\mathrm{EO}+\mathrm{ET})$, sprayed with essential oil (EO) only or distilled water (control, $\mathrm{CO})$. Means that are followed by the same letter are not significantly different based on Tukey's test $(\mathrm{P} \leq 0.05)$

Protein content was significantly different among treatments and the highest value was observed in the control plants $\left(21.8 \mu \mathrm{g} \mathrm{mL}^{-1}\right)$ (Figure 1A). Plants that were inoculated with B. maydis or E. turcicum did not differ between themselves, with protein contents of 15.2 and $16.3 \mu \mathrm{g} \mathrm{mL}^{-1}$, respectively. Lower protein content were observed in plants that were treated with essential oil of M. citrifolia alone or combined with B. maydis or E. turcicum inoculation, that showed a protein content of 8.4, 10.9 and $11.2 \mu \mathrm{g} \mathrm{mL}^{-1}$, respectively.

Statistical differences among the treatments were found regarding the CHI activity (Figure 1B). The highest enzyme activity $\left(0.027 \mu \mathrm{mol} \mu \mathrm{g}\right.$ protein $\left.{ }^{-1} \mathrm{~min}^{-1}\right)$ was observed in plants that were inoculated with E. turcicum, whereas the lowest activity $\left(0.015 \mu \mathrm{mol} \mu \mathrm{g}\right.$ protein $\left.{ }^{-1} \mathrm{~min}^{-1}\right)$ was verified in the control plants.

Both CAT (Figure 1C) and APX (Figure 1E) activities did not show any significant difference among treatments, indicating that neither the essential oil of $M$. citrifolia nor pathogen inoculation triggered CAT and APX synthesis.

A significant difference was found for SOD activity between control and the other treatments (Figure 1D). The lowest enzyme activity was recorded in the control plants $\left(0.009 \mu \mathrm{mol} \mu \mathrm{g}\right.$ protein $\left.{ }^{-1} \mathrm{~min}^{-1}\right)$. In response to $B$. maydis and E. turcicum inoculation, corn plants did not show differences between themselves, but they were different from the other treatments. Plants that were sprayed with the essential oil of $M$. citrifolia and those were sprayed with the essential oil and inoculated with $B$. maydis or E. turcicum were not different among themselves (enzyme activities were 0.098, 0.094 and $0.099 \mu \mathrm{mol} \mu \mathrm{g}$ protein ${ }^{-1} \mathrm{~min}^{-1}$, respectively). 
There was a significant difference for POX activity between the control and the treatments that received essential oil spraying and those with essential oil spraying and E. turcicum inoculation; the latter two treatments were not different from the other treatments. The control plants showed the lowest enzyme activity $\left(1.4 \mu \mathrm{mol} \mu \mathrm{g}\right.$ protein ${ }^{-1}$ $\min ^{-1}$ ) (Figure 1F).

\section{Discussion}

Despite the importance of SLB and NLB in reducing corn yield in Brazil, their management is still challenging. Resistance and fungicides are available, but variation in races and fungicide sensitivity of the pathogen may become such strategies innefective. Essential oils provides an innovative and environmentally friendly alternative for disease control, but mechanisms of action remain poorly investigated. In this work, we provide novel evidences at the biochemical level of the effect of B. maydis and E. turcicum as well as the essential oil of M. citrifolia in corn leaves and shed light on the potential indirect effect of the essential oil in SLB and NLB control.

Plants that were treated with the essential oil of M. citrifolia and inoculated with B. maydis and E. turcicum displayed lower protein content, which was probably due to the higher consumption of proteins by the corn plants to increase their defense responses against biotic (pathogen infection) or abiotic (presence of the essential oil) stresses. It is well known that stressful conditions increase the demand for proteins involved in biochemical processes, or even the conversion of proteins into specific enzymes in order to equilibrate plant cells since all stresses change gene expression, which are manifested as an induction or repression in the proteins that are produced under normal conditions (Paz et al., 2001).

The highest activity of CHI was recorded in plants that were inoculated with E. turcicum, followed by those inoculated with B. maydis and by those inoculated with both pathogens and sprayed with the essential oil of $M$. citrifolia. Most likely, the presence of the pathogen may have activated CHI synthesis as a plant defense response. Since chitin is a major component of fungal cell wall, CHI plays an obvious role in plant defense. In addition, CHI releases inducers from the pathogen's cell wall, thus enabling plant to detect it and triggers other lines of defences (Barros et al., 2010). Apart from stopping pathogen's growth, CHI causes the simultaneous release of phytoalexin's elicitors from pathogen mycelia (Maia et al., 2014).

Generation of reactive oxygen species (ROS), including hydrogen peroxide $\left(\mathrm{H}_{2} \mathrm{O}_{2}\right)$ and superoxide $\left(\mathrm{O}_{2}{ }^{-}\right)$, is a common feature of plans that are attacked by pathogens (Debona et al., 2012). Corn plants that were inoculated with Stenocarpella macrospora displayed increased concentrations of $\mathrm{H}_{2} \mathrm{O}_{2}$ and malondialdehyde (an indicator ofdamage to cell membranse), thereby contributing to the intensification of lipid peroxidation upon damage to cell membranes caused by fungal infection (Bermúdez-Cardona et al., 2015). Given the cytotoxic potential of ROS, their removal by antioxidant enzymes may play a role in disease resistance (Debona et al., 2012). SOD represents the first line of defense against ROS by dismutating $\mathrm{O}_{2}^{-}$into $\mathrm{H}_{2} \mathrm{O}_{2}$ and $\mathrm{O}_{2}$ (Foyer \& Noctor, 2000). In our study, the inoculation with E. turcicum and B. maydis significantly increased SOD activity, but such increases were boosted by spraying the essential oil of M. citrifolia, demonstrating the potential of the essential oil in decreasing oxidative stress induced by fungal infection. Area under of the NLB progress curve was demonstrated to be decreased in preventive spray of the essential oil of M. citrifolia (Silva et al., 2017) and findings of the present study indicates that SOD may be involved in corn resistance to NLB mediated by the essential oil. Consistently, the lower development of macrospora leaf spot symptoms in corn leaves was associated with higher acitivity of SOD (Bermúdez-Cardona et al., 2015). By contrast, activities of APX and CAT, enzymes that are involved in $\mathrm{H}_{2} \mathrm{O}_{2}$ removal (Apel \& Hirt, 2004), did not display any change due to pathogen inoculation or essential oil spray.

POX is involved in lignification, being required for the final step of the polymerization of phenolic compounds to lignin (Debona et al., 2012). Polymerization of phenolic compounds, in turn, may affect fungal development through physical blockage, making cell walls more resistant to the mechanical penetration by the fungus, or through reduced nutrient diffusion from the host to the fungus or of the fungal enzymes and toxins to the host (Debona et al., 2012). POX activity was found to be increased in reponse to the spray of the essential oil of $M$. citrifolia as wel as in its combination with inoculation of E. turcicum. Therefore, the increase in POX activity as a result of the spray of the essential oil of $M$. citrifolia is thought to be involved in NLB resistance.

In conclusion, besides its well known direct action on pathogens, essential oil of M. citrifolia was demonstrated to stimulate activities of CHI, SOD and POX, which may play a role in the essential oil-afforded control of SLB and NLB. 


\section{References}

Apel, K., \& Hirt, H. (2004). Reactive oxygen species: Metabolism, oxidative stress, and signal transduction. Annual Review of Plant Biology, 55, 373-399. https://doi.org/10.1146/annurev.arplant.55.031903.141701

Balint-Kurti, P. J., \& Carson, M. L. (2006). Analysis of quantitative trait loci for resistance to southern leaf blight in juvenile maize. Phytopathology, 96, 221-225. https://doi.org/10.1094/PHYTO-96-0221

Barros, F. C., Sagata, E., Ferreira, L. C. C., \& Juliatti, F. C. (2010). Indução de resistência em plantas contra fitopatógenos. Bioscience Jounal, 26, 231-239. Retrieved from https:/www.seer.ufu.br/index.php/bioscien cejournal/article/view/7071/4684

Belcher, A. R., Zwonitzer, J. C., Santa Cruz, J., Krakowsky, M. D., Chung, C. L., Nelson, R., ... Balint-Kurti, P. J. (2012). Analysis of quantitative disease resistance to southern leaf blight and of multiple disease resistance in maize, using near-isogenic lines. Theoretical and Applied Genetics, 124, 433-445. https://doi.org/10.1007/s00122-011-1718-1

Bermúdez-Cardona, M. B., Bispo, W. M. S., \& Rodrigues, F. A. (2015). Physiological and biochemical alterations on maize leaves infected by Stenocarpella macrospora. Acta Physiologiae Plantarum, $37,158$. https://doi.org/10.1007/s11738-015-1916-6

Bradford, M. M. (1976). A rapid and sensitive method for the microgram quantities of protein utilizing the principle of protein-dye-binding. Analytical Biochemistry, 72, 248-254. https://doi.org/10.1016/0003-2697 (76)90527-3

Cakmak, I., \& Marschner, H. (1992). Magnesium deficiency and high light intensity enhance activities of superoxide dismutase, ascorbate peroxidase and glutathione reductase in bean leaves. Plant Physiology, 98, 1222-1227. https://doi.org/10.1104/pp.98.4.1222

Chen, Y. L., Mao, X. W., Wang, J. X., Wu, L. Y., Zhou, M. G., \& Hou, Y. P. (2018). Activity of the dinitroaniline fungicide fluazinam against Bipolaris maydis. Pesticide Biochemistry and Physiology, 148, 8-15. https://doi.org/10.1016/j.pestbp.2018.03.005

Debona, D., Rodrigues, F. A., Rios, J. A., \& Nascimento, K. J. T. (2012). Biochemical changes in the leaves of wheat plants infected by Pyricularia oryzae. Phytopathology, 102, 1121-1129. https://doi.org/10.1094/ PHYTO-06-12-0125-R

Del Longo, O. T., González, C. A., Pastori, G. M., \& Trippi, V. S. (1993). Antioxidant defences under hyperoxygenic and hyperosmotic conditions in leaves of two lines of maize with differential sensitivity to drought. Plant \& Cell Physiology, 34, 1023-1028. https://doi.org/10.1093/oxfordjournals.pcp.a078515

Foyer, C. H., \& Noctor, G. (2000). Oxygen processing in photosynthesis: Regulation and signaling. New Phytologist, 146, 359-388. https://doi.org/10.1046/j.1469-8137.2000.00667.x

Giannopolitis, C. N., \& Ries, S. K. (1977). Superoxide dismutases I. Occurrence in higher plants. Plant Physiology, 59, 309-314. https://doi.org/10.1104/pp.59.2.309

Hou, Y. P., Chen, Y. L., Wu, L. Y., Wang, J. X., Chen, C. J., \& Zhou, M. G. (2018). Baseline sensitivity of Bipolaris maydis to the novel succinate dehydrogenase inhibitor benzovindiflupyr and its efficacy. Pesticide Biochemistry and Physiology, in press. https://doi.org/10.1016/j.pestbp.2018.06.002

Kar, M., \& Mishra, D. (1976). Catalase, peroxidase, and polyphenoloxidase activities during rice leaf senescence. Plant Physiology, 57, 315-319. https://doi.org/10.1104/pp.57.2.315

Levy, Y., \& Cohen, Y. (1983) Biotic and environmental factors affecting infection of sweet corn with Exserohilum turcicum. Phytopathology, 73, 722-725. https://doi.org/10.1094/Phyto-73-722

Maia, A. J., Schwan-Estrada, K. R. F., Faria, C. M. D. R., Oliveira, J. S. B., Jardinetti, V. A., \& Batista, B. N. (2014). Óleo essencial de alecrim no controle de doenças e na indução de resistência em videira. Pesquisa Agropecuária Brasileira, 49, 330-339. https://doi.org/10.1590/S0100-204X2014000500002

Mourão, D. S. S., Pereira, T. S. F., Souza, D. J., Chagas Júnior, A. F., Dalcin, M. S., Veloso, R. A., ... Santos, G. R. (2017). Essential oil of Cymbopogon citratus on the control of the Curvularia leaf spot disease on maize. Medicines, 4, 62. https://doi.org/10.3390/medicines4030062

Nakano, Y., \& Asada, K. (1981). Hydrogen-peroxide is scavenged by ascorbate-specific peroxidase in spinach-chloroplasts. Plant and Cell Physiology, 22, 867-880. https://doi.org/10.1093/oxfordjournals. pcp.a076232 
Nguefack, J., Wulff, G. E., Dongmo, J. B. L., Fouelefack, F. R., Fotio, D., Mbo, J., \& Torp, J. (2013). Effect of plant extracts and an essential oil on the control of brown spot disease, tillering, number of panicles and yield increase in rice. European Journal of Plant Pathology, 137, 871-882. https://oi.org/10.1007/ s10658-013-0298-0

Paz, N. E., Aguirre, F. M., \& Ontiveros, J. L. R. (2001). Efecto del déficit hídrico en el patron electroforético de proteínas totals en dos variedades de maíz. Revista Fitotecnia Mexicana, 24, 121-128.

Pereira, R. B., Lucas, G. C., Perina, F. J., \& Alves, E. (2012). Essential oils for rust control on coffee plants. Ciência e Agrotecnologia, 36, 16-24. https://doi.org/10.1590/S1413-70542012000100002

Raymundo, A. D., \& Hooker, A. L. (1981). Measuring the relationship between northern corn leaf blight and yield losses. Plant Disease, 65, 325-327. https://doi.org/10.1094/PD-65-325

Silva, A. C., Souza, P. E., Amaral, D. C., Zeviani, W. M., \& Pinto, J. E. B. P. (2014). Essential oils from Hyptis marrubioides, Aloysia gratissima and Cordia verbenacea reduce the progress of Asian soybean rust. Acta Scientiarum - Agronomy, 36, 159-166. https://doi.org/10.4025/actasciagron.v36i2.17441

Silva, J. C. E., Mourão, D. S. S., Lima, F. S. O., Sarmento, R. A., Dalcin, M. S., Aguiar, R. W. S., \& Santos, G. R. R. (2017). The efficiency of noni (Morinda citrifolia L.) essential oil on the control of leaf spot caused by Exserohilum turcicum in maize culture. Medicines, 4, 60. https://doi.org/10.3390/medicines4030060

Singh, R., \& Srivastava, R. P. (2012). Southern corn leaf blight- an important disease of maize: An extension fact sheet. Indian Research Journal of Extension Education Special Issue, 1, 334-337. Retrieved from https://www.seea.org.in/irjee/upload/v12469.pdf

Tefferi, A., Hulluka, M., \& Welz, H. G. (1996). Assessment of damage and grain yield loss in maize caused by northern leaf blight in western Ethiopia. Journal of Plant Disease Protection, 103, 353-363. https://doi.org/ 10.20546/ijcmas.2017.603.097

Ullstrup, A. J. (1972). The impacts of the southern corn leaf blight epidemic of 1970-1971. Annual Review of Phytopathology, 10, 37-50. https://doi.org/10.1146/annurev.py.10.090172.000345

USDA (United States Department of Agriculture). (2018). World Agriculture Production. Circular Series WAP June 6-18, 2018. Retrieved from https://apps.fas.usda.gov/psdonline/circulars/production.pdf

Wirth, S. J., \& Wolf, G. A. (1990). Dye-labeled substrates for the assay and detection of chitinase and lysozyme activity. Journal of Microbiological Methods, 12, 197-205. https://doi.org/10.1016/0167-7012(90)90031-Z

\section{Copyrights}

Copyright for this article is retained by the author (s), with first publication rights granted to the journal.

This is an open-access article distributed under the terms and conditions of the Creative Commons Attribution license (http://creativecommons.org/licenses/by/4.0/). 